\title{
Sistem Pendukung Keputusan Penentuan Penerima Kredit Usaha (Studi Kasus: Adira Finance Kediri)
}

\author{
Decision Support System Determining Business Loan Recipients \\ (Case Study: Adira Finance Kediri) \\ Yudo Bismo Utomo ${ }^{1}$, Joang Ipmawati ${ }^{2}$ \\ ${ }^{1,2}$ Magister Teknik Informatika STMIK AMIKOM Yogyakarta \\ E-mail: ${ }^{1}$ bismo_kdr@yahoo.com, ${ }^{2}$ joangipmawati@gmail.com
}

\begin{abstract}
Abstrak
Program pemerintah dalam mengurangi jumlah pengangguran di negara ini adalah dengan jalan memberikan kredit untuk usaha kepada para nasabah calon pengusaha. Dalam hal ini, PT. Adira Finance yang bergerak di bidang perkreditan ikut andil dalam rencana pemerintah tersebut. Metode yang dilakukan PT. Adira Finance saat ini dalam mengambil keputusan penentuan kelayakan penerima kredit masih menggunakan cara manual, sehingga membutuhkan waktu yang lama untuk menentukan nasabah tersebut layak atau tidak menerima kredit. Untuk itu maka perlu dibuatlah aplikasi sistem pendukung keputusan penentuan kelayakan penerima kredit dengan metode Neural Network algoritma backpropagation. Dari hasil uji coba yang telah dilakukan, dengan parameter learning rate sebesar 0.9; hidden layer 10; maksimum epoch 1000 dan target error $10^{-5}$ menghasilkan akurasi yang cukup baik yaitu $98 \%$. Aplikasi telah didesain mampu memenuhi kebutuhan pihak Pimpinan PT. Adira Finance dalam menentukan nasabah mana yang layak menerima kredit.
\end{abstract}

Kata Kunci - Sistem Pendukung Keputusan, kredit, neural network, backpropagation.

\begin{abstract}
Government programs to reduce the number of unemployed in this country is by providing credit to businesses to customers aspiring entrepreneurs. In this case, PT. Adira Finance engaged in credit took part in the government plan. The method is carried PT. Adira Finance today in making a decision on the merits of credit recipients still use manual way, so it takes a long time to determine the customer is feasible or not receive credit. For that it needs to be made to decision support system application credit recipient eligibility determination by the method of propagation Neural Network algorithm. From the results of trials that have been done, the learning rate parameter of 0.9; hidden layer 10; the maximum error epoch 1000 and targets $10^{-5}$ generates good accuracy of $98 \%$. The app has been designed to meet the needs PT. Adira Finance Leaders parties in determining which customers are eligible to receive credit.
\end{abstract}

Keywords — Decision Support System, credit, neural network, backpropagation.

\section{PENDAHULUAN}

Sebagaimana diketahui di era pemerintahan Susilo Bambang Yudhoyono, salah satu program andalan untuk pengentasan kemiskinan adalah Kredit Usaha Rakyat (KUR). Dan di era pemerintahan Jokowi saat ini melanjutkan salah satu program yang dirintis oleh SBY tersebut. Diharapkan dari program tersebut bisa mengurangi jumlah pengangguran di negara ini. Dalam hal ini, PT. Adira Dinamika Multi Finance Tbk (Adira Finance) yang mempunyai banyak aktivitas dimana salah satunya adalah melayani kegiatan perkreditan mampu merealisasikan program dari pemerintah tersebut. 
Adira Finance memberikan kredit kepada para nasabah setiap calon pengusaha dengan kriteria yang sudah ditetapkan oleh perusahaan. Perkembangan teknologi yang semakin pesat sehingga suatu perusahaan tidak terlepas dari penggunaan komputer sebagai pengolah data. Cara manual mungkin juga dapat dilakukan jika jumlah data yang diolah sedikit, akan tetapi jika jumlah data yang diolah sangat banyak kemungkinan dapat menyebabkan kesalahan dalam pengolahan data. Begitu juga di perusahaan Adira Finance, banyaknya data pemohon kredit untuk modal usaha menyebabkan kesulitan bagi perusahaan sehingga membutuhkan waktu yang cukup lama untuk menentukan nasabah mana yang layak menerima kredit. Hal ini memungkinkan pihak Adira melakukan kesalahan saat menganalisis karena kurangnya kontrol sehingga calon nasabah yang tidak memenuhi kriteria layak mendapatkan kredit begitu juga sebaliknya.

Untuk meminimumkan kesalahan seperti yang dijelasakan di atas, maka peneliti mencoba membuat sebuah aplikasi sistem pendukung keputusan penentuan kelayakan penerima kredit usaha di Adira Finance. Untuk permasalahan tersebut digunakan suatu metode yaitu Neural Network algoritma Backpropagation. Backpropagation merupakan algoritma jaringan syaraf tiruan yang memiliki pembelajaran yang terawasi (supervised learning). Backpropagation menggunakan error output untuk mengubah nilai bobot-bobotnya dalam arah mundur (backward). Untuk mendapatkan error ini maka dilakukan perambatan maju dengan menggunakan fungsi aktifitas sigmoid biner.

Dengan adanya aplikasi tersebut, diharapkan dapat membantu pihak perusahaan Adira dalam menentukan siapa pemohon kredit yang layak menerima kredit atau tidak dengan sistem yang terkomputerisasi sehingga proses pengambilan keputusan ini lebih efisien, hemat waktu dan hemat biaya.

Tujuan dari penelitian ini adalah untuk dapat membantu perusahaan Adira Finance dalam menentukan siapa pemohon kredit yang layak menerima kredit atau tidak. Sedangkan batasan masalah dalam penelitian ini adalah: 1) Sistem pendukung keputusan kelayakan penerima kredit usaha di Adira Finance menggunakan metode neural network backpropagation, 2) menggunakan aktivasi sigmoid biner, 3) Kriteria terdiri dari: lama usaha, prestasi nasabah, jangka waktu, jaminan dan pendapatan per-bulan.

Dalam penelitian sebelumnya, [1] melakukan penelitian sistem pendukung keputusan penilaian kelayakan pemberian kredit menggunakan metode bayes, dimana penelitian ini mengambil studi kasus di Bank BRI menggunakan kriteria 5C, yaitu : 1) Character, 2) Capital, 3) Capacity, 4) Collateral dan 5) Condition of Economi. Hasil yang di dapat adalah layak tidaknya calon debitur untuk mendapatkan kredit. Sedangkan penelitian yang dilakukan oleh [2] tentang sistem pendukung keputusan pemberian kredit usaha rakyat menggunakan metode SAW, dimana penelitian ini mengambil studi kasus di Bank Syariah Mandiri. Hasil penelitiannya sama dengan penelitian yang dilakukan oleh [1], akan tetapi kriteria yang digunakan berbeda yaitu menggunakan : 1) penghasilan, 2) usia, 3) jenis usaha, 4) jumlah tanggungan dan status kependudukan serta 5) Rekening listrik dan rekening bank. Hal ini diperkuat oleh penelitian yang dilakukan oleh [3] tentang sistem pendukung keputusan pemberian kredit di koperasi dengan menggunakan metode tsukamoto, hasil yang didapatkan adalah layak tidaknya calon debitur mendapatkan kredit.

Untuk penelitian yang dilakukan oleh [4], [5] dan [6] dengan menggunakan metode yang sama yaitu jaringan syaraf tiruan backpropagation dengan studi kasus yang berbeda, hasil yang diperoleh dalam penelitian tersebut sama, yaitu target output yang diinginkan lebih mendekati ketepatan dalam melakukan pengujian karena terjadi penyesuaian nilai bobot dan bias yang semakin baik pada saat proses training atau pelatihan.

\subsection{Sistem Pendukung Keputusan}

Sistem Pendukung Keputusan (SPK) merupakan sistem informasi interaktif yang menyediakan informasi, pemodelan dan pemanipulasi data. Sistem ini digunakan untuk membantu pengambilan keputusan dalam situasi semi terstuktur dan situasi yang tidak terstruktur, dengan tak seorangpun tahu secara pasti cara keputusan yang seharusnya dibuat. Definisi SPK 
yang dikemukakan oleh Keen dan Scot Morton yaitu suatu sistem pendukung yang berbasis komputer yang diberikan kepada pengambil keputusan dalam bidang manajemen untuk memecahkan masalah yang semi terstruktur.

Dengan pengertian diatas dapat dijelaskan bahwa sistem pendukung keputusan bukan merupakan alat pengambilan keputusan, melainkan merupakan sistem yang membantu pengambil keputusan dengan melengkapi mereka dengan informasi dari data yang telah diolah dengan relevan dan diperlukan untuk membuat keputusan tentang suatu masalah dengan lebih cepat dan akurat. Sehingga sistem ini tidak dimaksudkan untuk menggantikan pengambilan keputusan dalam proses pembuatan keputusan.

Jenis-jenis keputusan dikelompokan menjadi 2, antara lain:

1. Keputusan Terprogram

Keputusan ini bersifat berulang dan rutin, sedemikian hingga suatu prosedur pasti telah dibuat menanganinya sehingga keputusan tersebut tidak perlu diperlakukan sebagai sesuatu yang baru tiap kali terjadi.

2. Keputusan Tak Terprogram

Keputusan ini bersifat baru, tidak terstruktur dan jarang konsisten. Tidak ada metode yang pasti untuk menangani masalah tersebut.

\subsection{Kredit}

Dalam bahasa sehari-hari, kata kredit sering diartikan memperoleh barang atau uang setelah itu cara pembayarannya dengan cara mencicil atau mengangsur dikemudian hari sesuai dengan perjanjian. Jadi dapat diartikan bahwa kredit dapat berbentuk barang maupun uang. Baik kredit berbentuk barang maupun uang dalam hal pembayarannya adalah dengan menggunakan metode angsuran atau cicilan tertentu. Kredit dalam bentuk uang lebih dikenal dengan istilah pinjaman.

Menurut asal mulanya kata kredit berasal dari kata credere yang artinya adalah kepercayaan, maksudnya adalah apabila seseorang memperoleh kredit berarti mereka memperoleh kepercayaan. Sedangkan bagi si pemberi kredit artinya memberikan kepercayaan kepada seseorang bahwa uang yang dipinjamkan pasti kembali.

Manusia memerlukan kredit karena manusia adalah homo economicus dan setiap manusia selalu berusaha untuk memenuhi kebutuhannya. Kebutuhan manusia beraneka ragam sesuai dengan hasratnya yang selalu meningkat, sedangkan kemampuannya untuk mencapai sesuatu yang diinginkan terbatas. Hal ini yang menyebabkan manusia memerlukan bantuan untuk memenuhi hasrat dan cita-citanya, dalam hal ini ia berusaha. Maka untuk meningkatkan usahanya atau untuk meningkatkan daya guna suatu barang, manusia sangat memerlukan bantuan dalam bentuk permodalan.

Seperti yang dijelaskan diatas bahwa pemberian kredit adalah pemberian kepercayaan. Hal ini berarti bahwa pinjaman kredit yang diberikan betul-betul yakin bahwa nasabah akan mengembalikan pinjaman yang diterima sesuai dengan jangka waktu dan syarat-syarat yang akan disetujui oleh kedua belah pihak, tanpa keyakinan tersebut suatu lembaga kredit tidak akan dapat memberikan kredit.

\subsection{Neural Network}

Jaringan Saraf Tiruan atau neural network adalah paradigma pengolahan informasi yang terinspirasi oleh sistem saraf secara biologis, seperti proses informasi pada otak manusia. Elemen kunci dari paradigma ini adalah struktur dari sistem pengolahan informasi yang terdiri dari sejumlah besar elemen pemrosesan yang saling berhubungan (neuron), bekerja serentak untuk menyelesaikan masalah tertentu. Cara kerja JST seperti cara kerja manusia, yaitu belajar melalui contoh. Sebuah JST dikonfigurasikan untuk aplikasi tertentu, seperti pengenalan pola atau klasifikasi data, melalui proses pembelajaran . 
Berdasarkan model matematis, baik tidaknya suatu model JST ditentukan oleh hal-hal sebagai berikut:

1. Arsitektur jaringan, yaitu sebuah arsitektur yang menentukan pola antar neuron

2. Metode pembelajaran (learning method), yaitu metode yang digunakan untuk menentukan dan mengubah bobot

3. Fungsi aktivasi

Baik tidaknya suatu model JST salah satunya ditentukan oleh hubungan antar neuron atau yang biasa disebut sebagai arsitektur jaringan. Neuron- neuron tersebut terkumpul dalam lapisanlapisan yang disebut neuron layer. Lapisan-lapisan penyusun JST dibagi menjadi tiga, yaitu:

1. Lapisan input (input layer)

Unit-unit dalam lapisan input disebut unit-unit input yang bertugas menerima pola inputan dari luar yang menggambarkan suatu permasalahan.

2. Lapisan tersembunyi (hidden layer)

Unit-unit dalam lapisan tersembunyi disebut unit-unit tersembunyi, yang mana nilai outputnya tidak dapat diamati secara langsung.

3. Lapisan output (output layer)

Unit-unit dalam lapisan output disebut unit-unit output, yang merupakan solusi JST terhadap suatu permasalahan.

\subsection{Backpropagation}

Backpropagation merupakan algoritma pembelajaran yang terawasi dan biasanya digunakan oleh perceptron dengan banyak lapisan untuk mengubah bobot-bobot yang terhubung dengan neuron-neuron yang ada pada lapisan tersembunyinya. Algoritma backpropagation menggunakan error output untuk mengubah nilai bobot-bobotnya dalam arah mundur (backward). Untuk mendapatkan error ini, tahap perambatan maju (forward propagation) harus dikerjakan terlebih dahulu. Pada saat perambatan maju, neuron-neuron diaktifkan dengan menggunakan fungsi aktivasi sigmoid.

Fungsi aktivasi sigmoid ini digunakan untuk jaringan saraf yang dilatih dengan menggunakan metode backpropagation. Fungsi sigmoid biner memiliki nilai pada range 0 sampai 1. Oleh karena itu, fungsi ini sering digunakan untuk jaringan saraf yang membutuhkan nilai output yang terletak pada interval 0 sampai 1 . Namun, fungsi ini bisa juga digunakan oleh jaringan saraf yang nilai output 0 atau 1.

\section{METODE PENELITIAN}

\subsection{Tipe Penelitian}

Jenis penelitian yang digunakan dalam pembuatan sistem pendukung keputusan ini adalah deskriptif dan empiris. Penelitian deskriptif adalah penelitian yang dalam pelaksanaannya meliputi data, analisis dan implementasi setelah data sudah diperoleh. Sedangkan empiris adalah meneliti langsung peristiwa yang ada di lapangan.

\subsection{Metode Pengumpulan Data}

Dalam melakukan penelitian untuk mendapatkan data dan informasi, maka metode yang digunakan dalam proses pengumpulan data dilakukan sebagai berikut:

1. Metode Observasi

Dalam hal ini yang akan dilakukan adalah melihat serta mempelajari permasalahan yang ada di lapangan yang erat kaitannya dengan obyek yang akan diteliti yaitu mengenai sistem penerimaan kelayakan kredit usaha. 
2. Metode Studi Pustaka

Metode yang dilakukan adalah dengan cara mencari bahan yang mendukung dalam pendefisian masalah melalui buku-buku, internet, yang erat kaitannya dengan obyek permasalahan.

3. Metode Analisa Data

Sistem pendukung keputusan yang akan dibuat menggunakan metode neural network algoritma backpropagation untuk menentukan nasabah mana yang layak menerima kredit usaha dengan criteria yang sudah ditentukan oleh pihak Adira Finance.

\section{HASIL DAN PEMBAHASAN}

\subsection{Kriteria-Kriteria Yang Digunakan}

Untuk kriteria-kriteria yang digunakan dalam penelitian ini adalah sebagai berikut:

$\mathrm{X} 1$ = Lama Usaha

$\mathrm{X} 2$ = Prestasi nasabah

$\mathrm{X} 3$ = Jangka waktu

$\mathrm{X} 4$ = Jaminan

$\mathrm{X} 5$ = Pendapatan per-bulan

\subsection{Arsitektur Jaringan Neural Network}

Di dalam arsitektur jaringan neural network terdapat 3 layer, yaitu: layer input, hidden layer dan layer output. Untuk layer input diperoleh dari data kriteria, sedangkan hidden layer yaitu layer tersembunyi dan layer output adalah hasil keluaran. Gambar 1 merupakan desain arsitektur jaringan neural network sistem pendukung keputusan penentuan penerima kredit di Adira Finance Kediri.

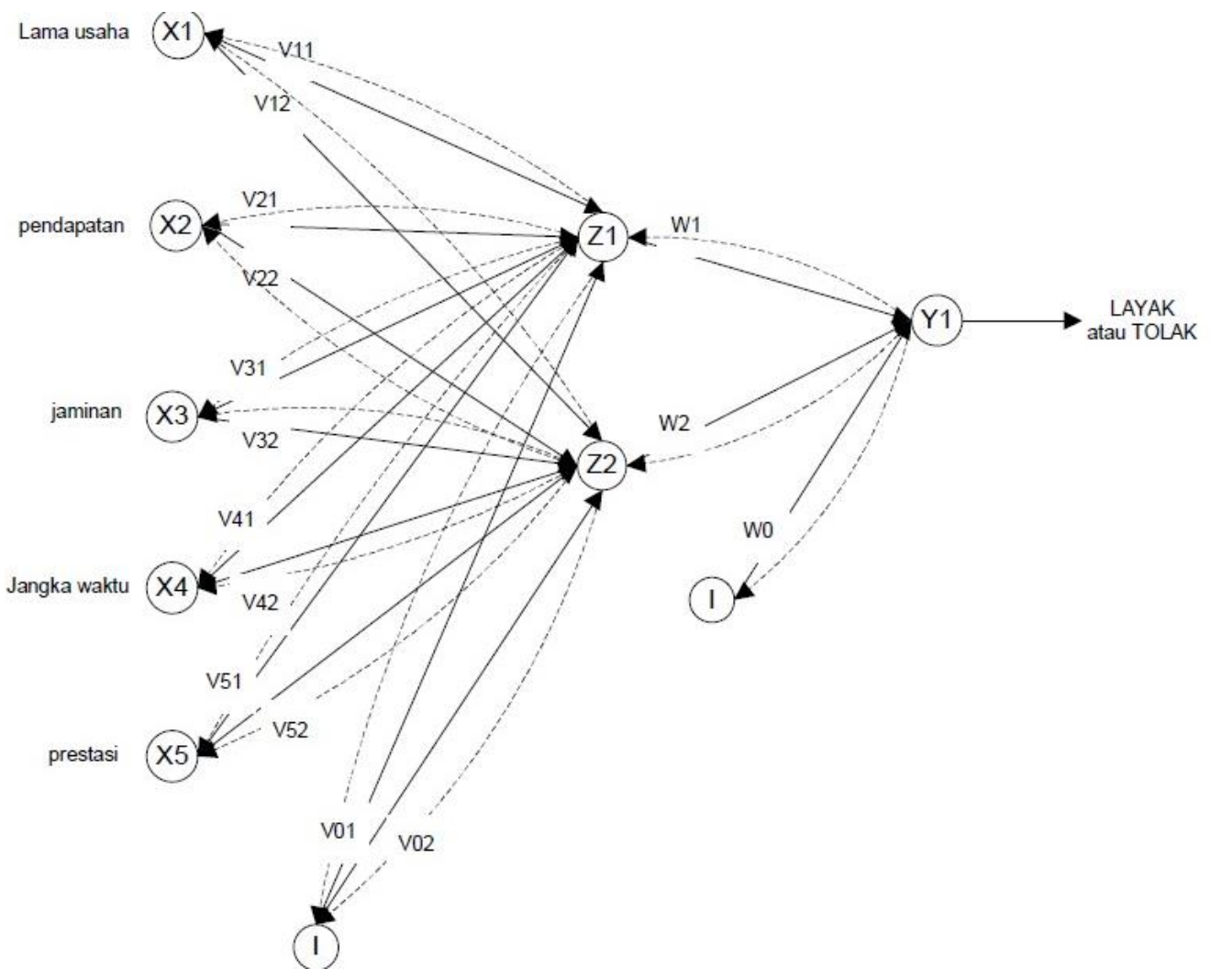

Gambar 1. Arsitektur Jaringan Neural Network 


\subsection{Perancangan Sistem}

Dalam perancangan sistem ini penulis menggunakan DFD (Data Flow Diagram) yaitu sebagai berikut:

1. DFD level 0

Di dalam DFD level 0 ini menggambarkan ada 2 user yang bisa mengakses sistem pendukung keputusan yaitu manager dan admin. Untuk manager hanya bisa melihat laporan nasabah yang layak atau tidak menerima kredit. Sedangkan admin menginput data nasabah, kriteria, petugas survey, training dan testing. Dan sistem memberikan feedback ke admin berupa laporan nasabah yang layak atau tidak menerima kredit.Gambar 2 adalah gambar DFD level 0.

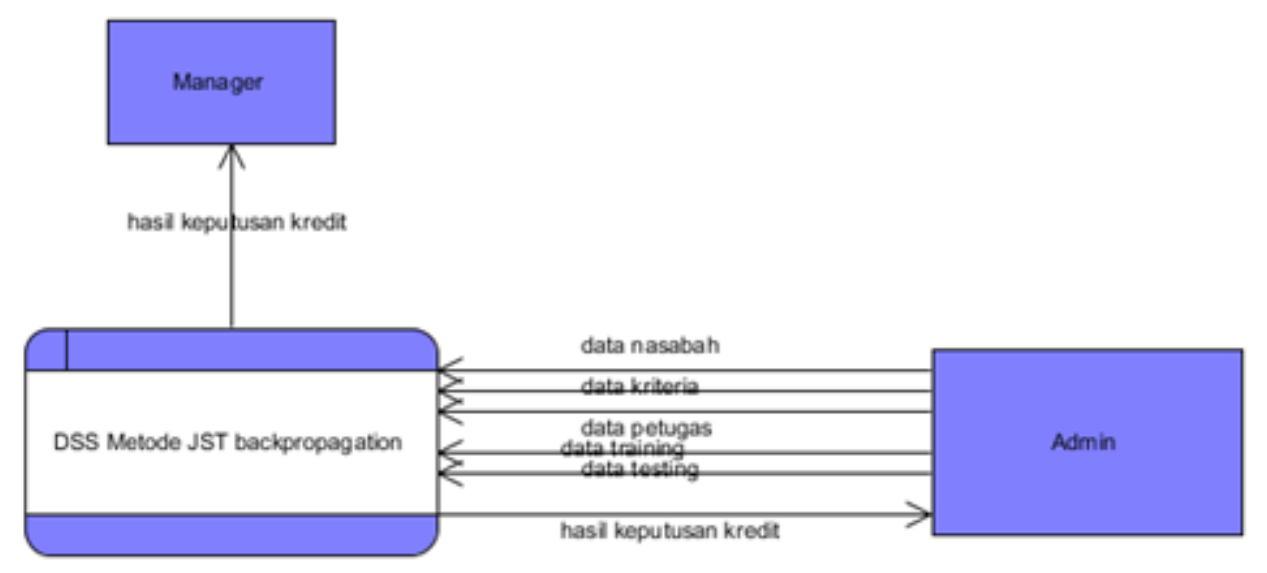

Gambar 2. DFD level 0

2. DFD level 1

DFD level 1 adalah turunan dari DFD level 0. Gambar 3 merupakan DFD level 1.

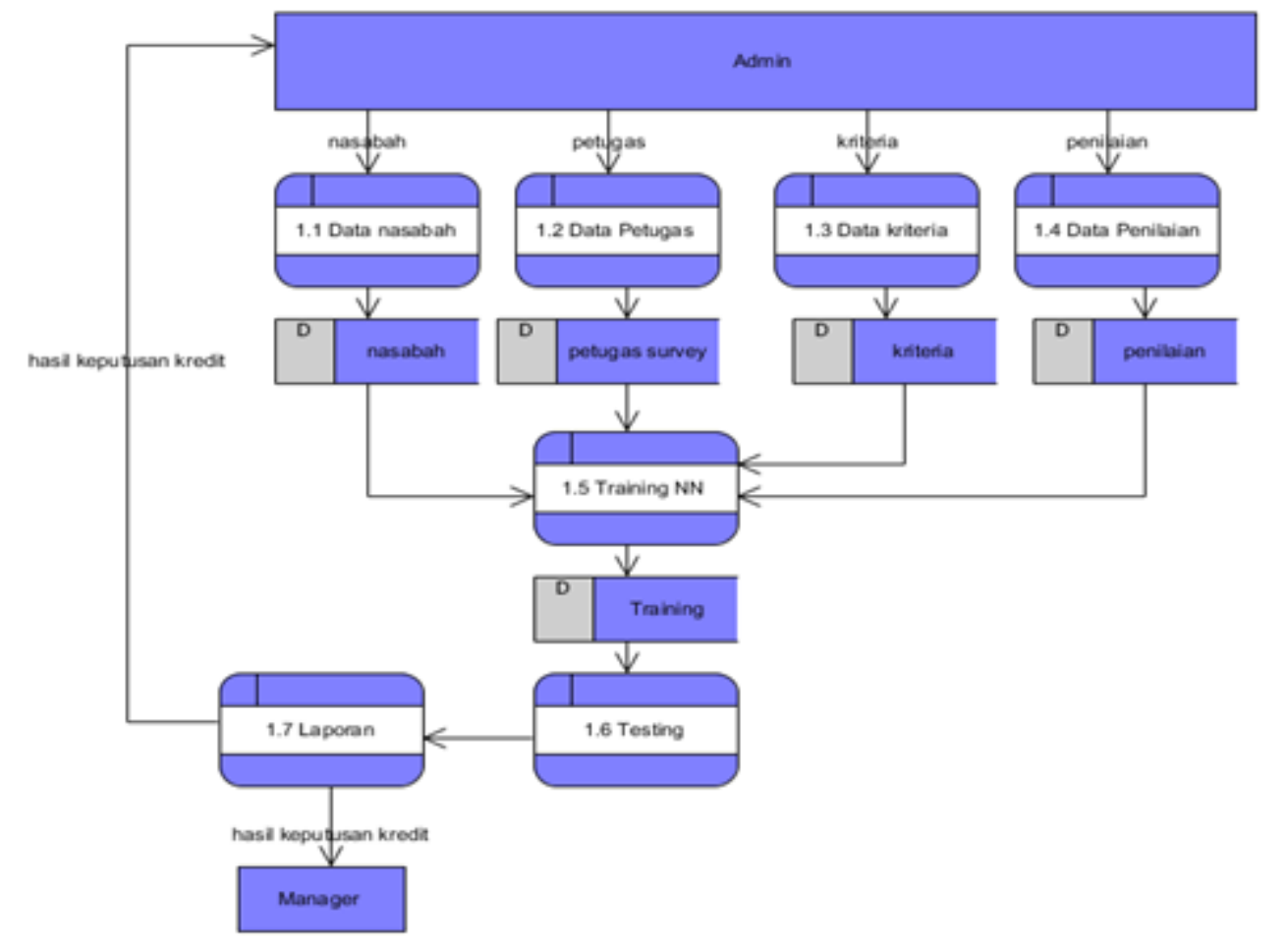

Gambar 3. DFD level 1 
Citec Journal, Vol. 3, No. 4, Agustus 2016 - Oktober 2016

\subsection{Perancangan Database}

Dalam perancangan database ini penulis menggunakan ERD (Entity Relationship Diagram) yaitu sebagai berikut:

\section{ERD (Entity Relationship Diagram)}

Di dalam ER-Diagram ini menggambarkan ada 5 tabel database yang akan dibangun yaitu nasabah, proses, tes dan survey. Gambar 4 adalah gambar DFD level 0.

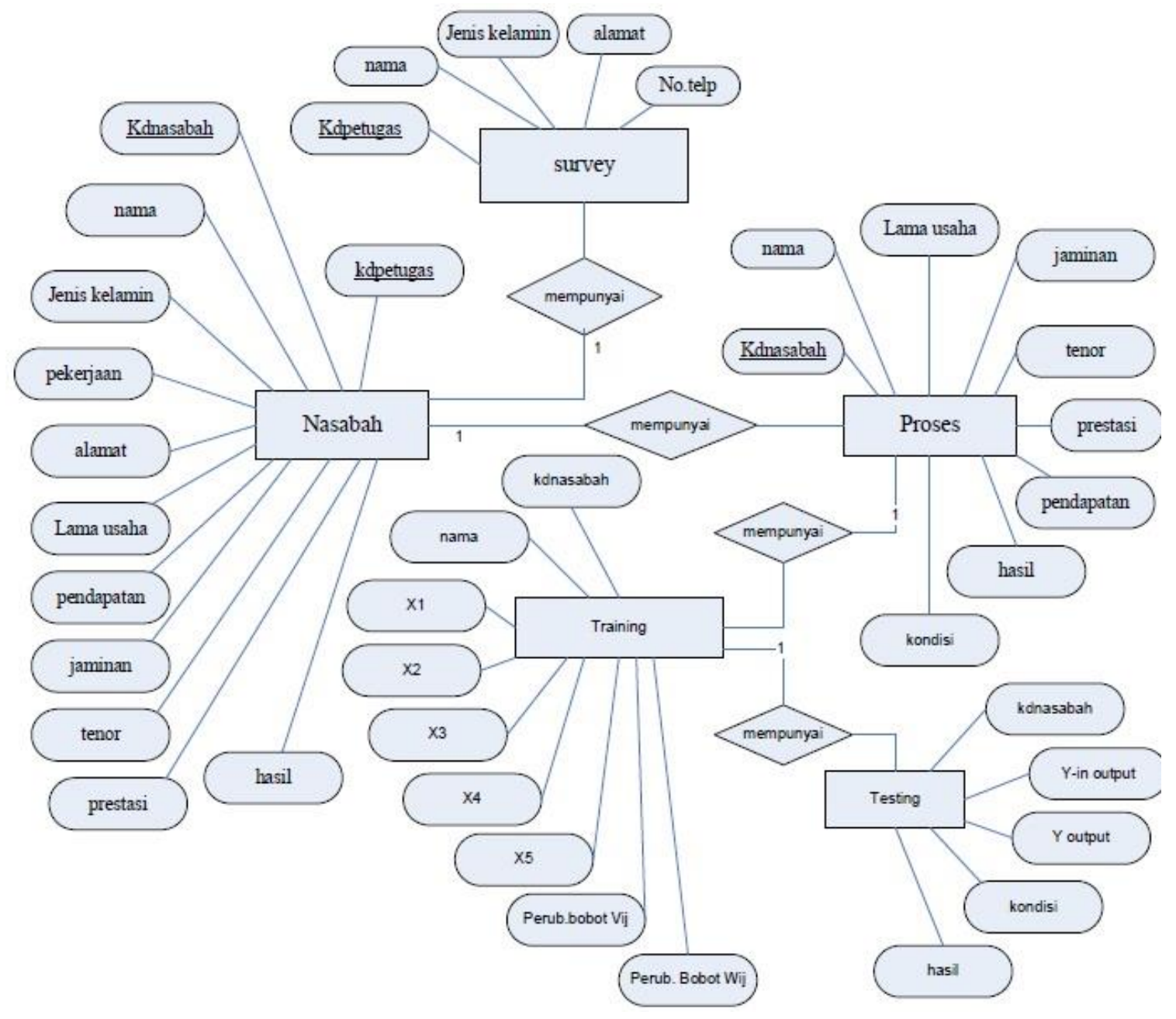

Gambar 4. ER-Diagram 
2. Diagram Hubungan Entitas

Selanjutnya dalam perancangan detilnya mencakup database. Pokok pemikiran dalam merancang database adalah bagaimana merancang database sehingga dapat memenuhi kebutuhan saat ini dan kemudahannya untuk dikembangkan di masa yang akan datang. Gambar 5 adalah gambaran hubungan entitas antar tabel database:

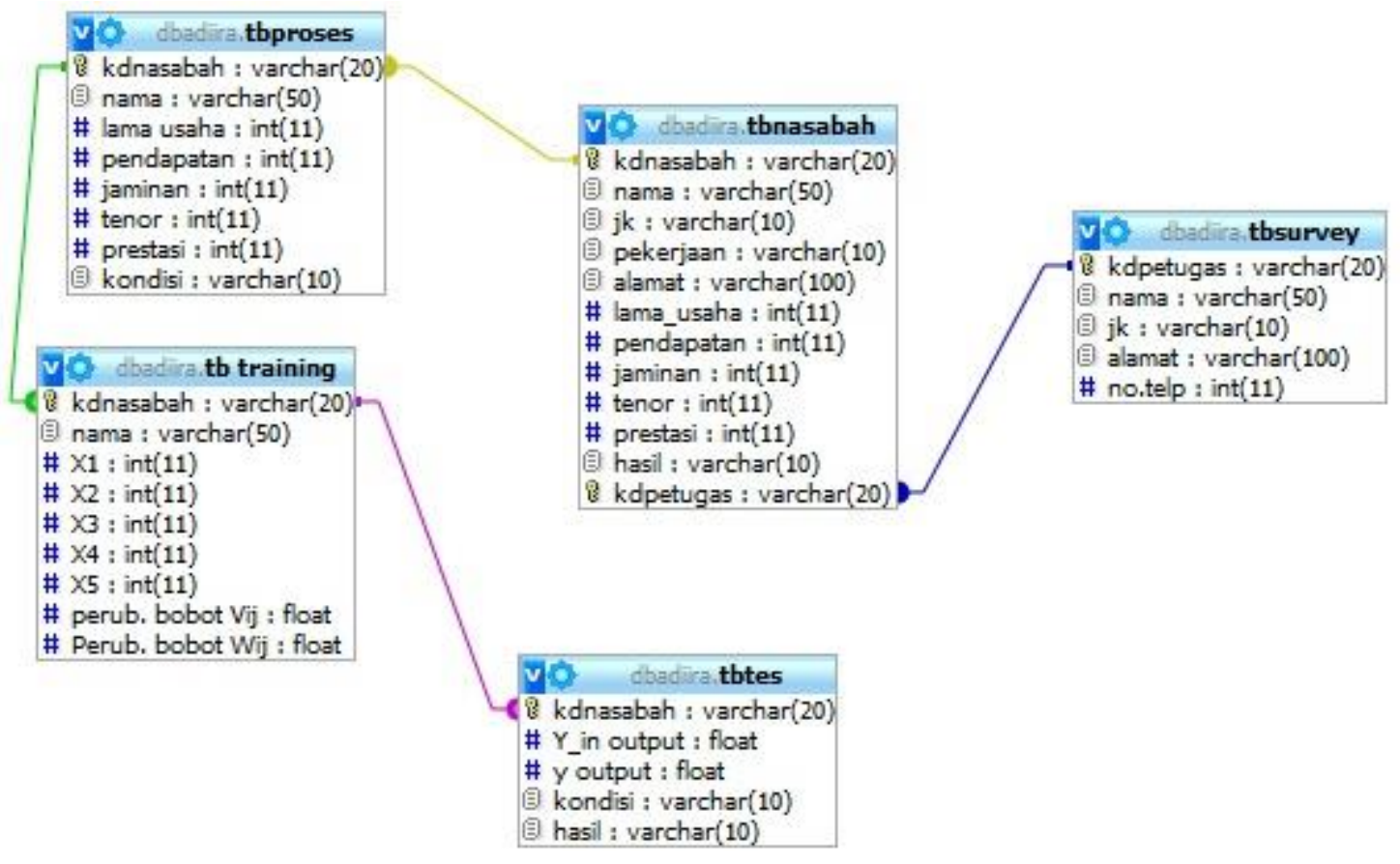

Gambar 5. Diagram Hubungan Entitas 
Citec Journal, Vol. 3, No. 4, Agustus 2016 - Oktober 2016

\subsection{Hasil Rancangan Sistem}

Hasil rancangan sistem pendukung keputusan penentuan penerima kredit usaha di adira finance adalah sebagai berikut:

1. Form Data Nasabah

Di dalam form data nasabah terdapat nama-nama nasabah yang melakukan kredit di Adira Finance yang telah di survey terlebih dahulu oleh petugas lapangan, ditunjukkan pada Gambar 6.

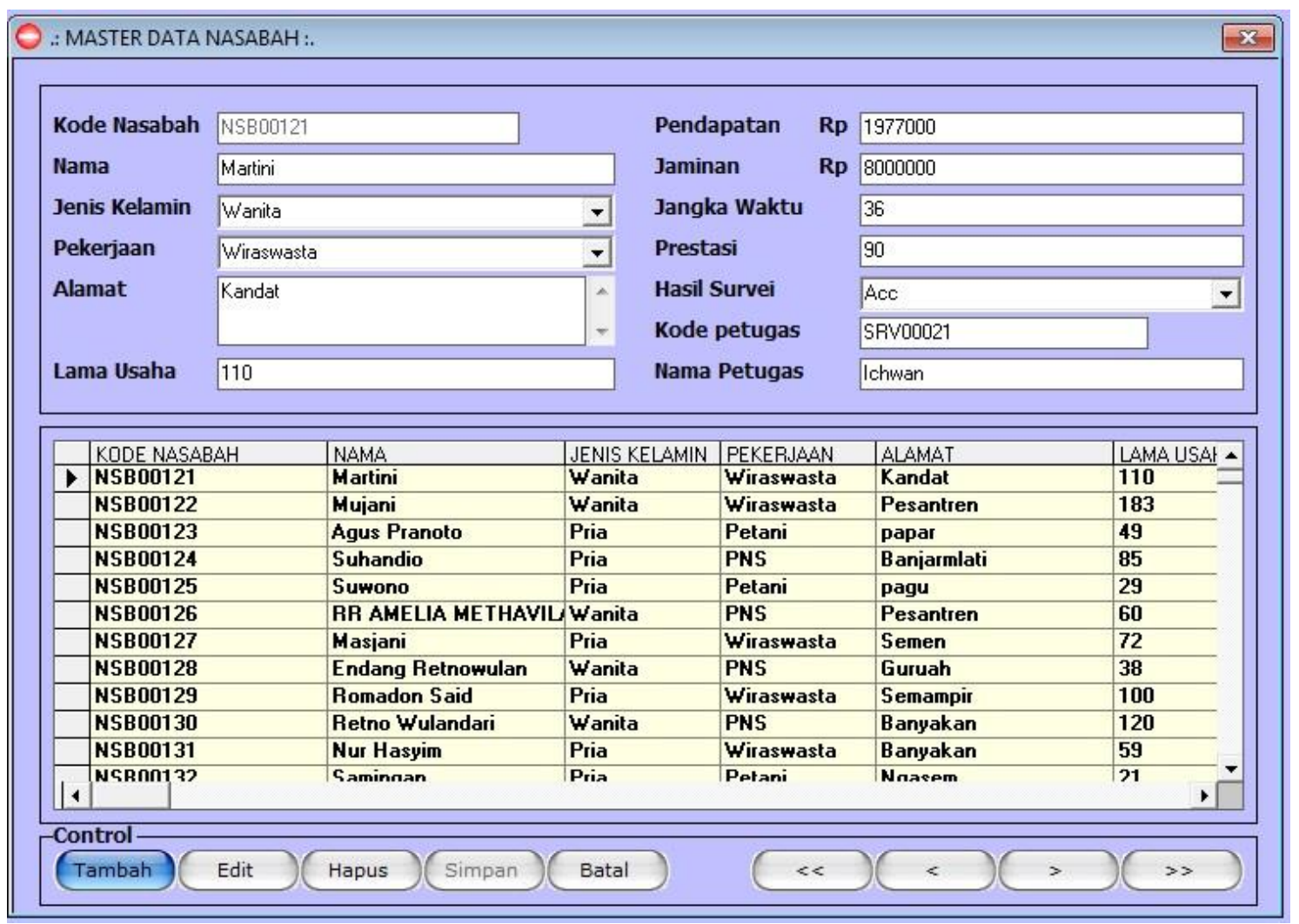

Gambar 6. Form Data Nasabah 
2. Form Data Petugas Survey

Di dalam form petugas survey terdapat nama-nama petugas Adira yang melakukan survey nasabah di lapangan, ditunjukkan pada Gambar 7.

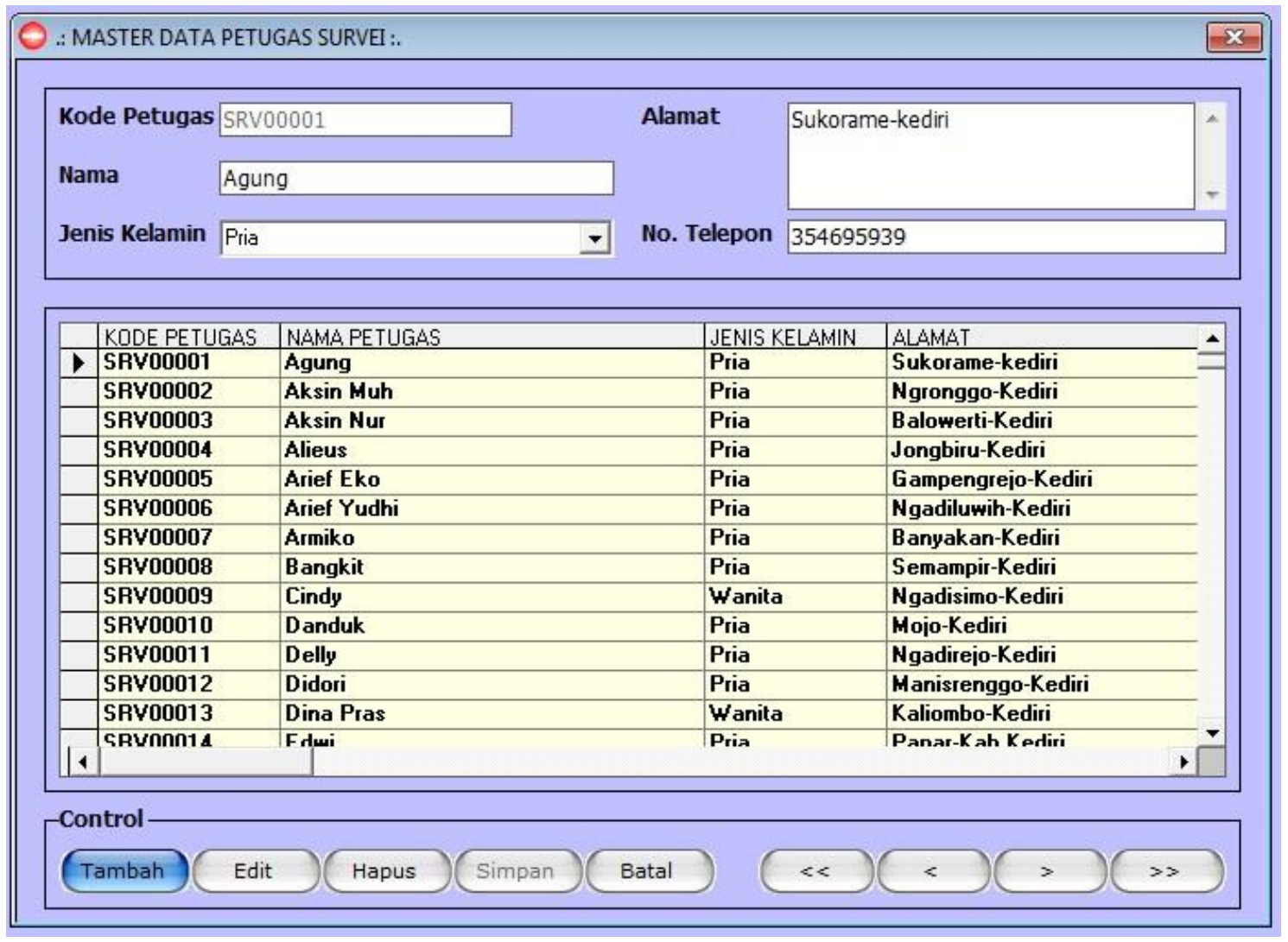

Gambar 7. Form Petugas Survey

3. Form Proses Neural Network

Di dalam proses Neural Network ini, admin menginputkan nilai learning rate, hidden layer, max.epoch dan target error untuk dimasukkan ke dalam proses training, seperti pada Gambar 8.

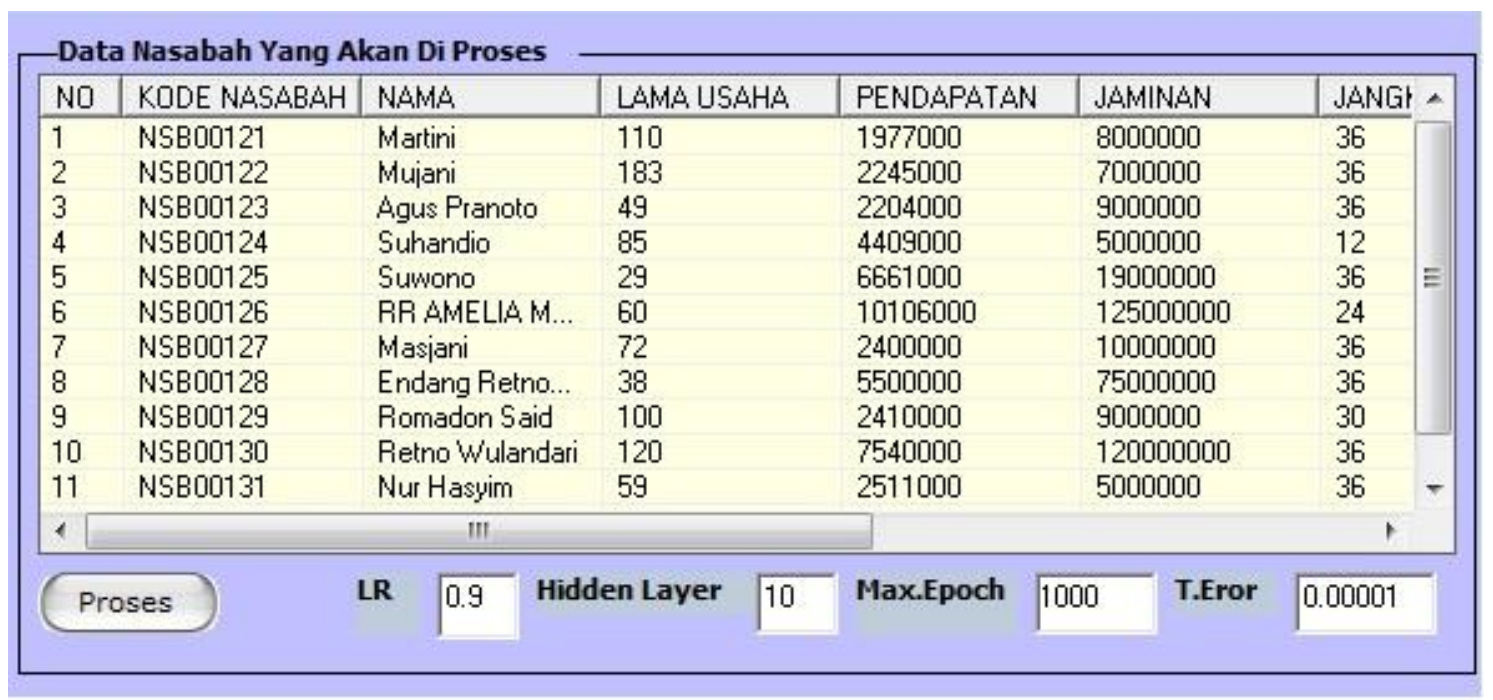

Gambar 8. Form Proses Neural Network 
Citec Journal, Vol. 3, No. 4, Agustus 2016 - Oktober 2016

ISSN: 2460-4259

4. Form Training Neural Network

Setelah data nasabah dimasukkan ke proses perhitungan, maka akan dilakukan training oleh sistem untuk mendapatkan bobot baru. Di dalam proses training ini, akan memakai 100 nasabah, dan sisanya akan dilakukan proses testing. Proses training ditunjukkan pada Gambar 9.

\begin{tabular}{|c|c|c|c|c|c|c|c|}
\hline \multicolumn{8}{|c|}{ Proses Training Data Nasabah } \\
\hline NO & KODE NASABAH & NAMA & $x 1$ & $x_{2}$ & $\times 3$ & $\times 4$ & * \\
\hline 1 & NSB00121 & Martini & 110 & 1977000 & 8000000 & 36 & \multirow{13}{*}{$\equiv$} \\
\hline 2 & NSB00122 & Mujani & 183 & 2245000 & 7000000 & 36 & \\
\hline 3 & NSB00123 & Agus Pranoto & 49 & 2204000 & 9000000 & 36 & \\
\hline 4 & NSB00124 & Suhandio & 85 & 4409000 & 5000000 & 12 & \\
\hline 5 & NSBO0125 & Suwono & 29 & 6661000 & 19000000 & 36 & \\
\hline 6 & NSB00126 & RR AMELIA M... & 60 & 10106000 & 125000000 & 24 & \\
\hline 7 & NSB00127 & Masjani & 72 & 2400000 & 10000000 & 36 & \\
\hline 8 & NSB00128 & Endang Retno... & 38 & 5500000 & 75000000 & 36 & \\
\hline 9 & NSB00129 & Romadon Said & 100 & 2410000 & 9000000 & 30 & \\
\hline 10 & NSB00130 & Retno Wulandari & 120 & 7540000 & 120000000 & 36 & \\
\hline 11 & NSB00131 & Nur Hasyim & 59 & 2511000 & 5000000 & 36 & \\
\hline 12 & NSB00132 & Samingan & 21 & 1503000 & 5000000 & 36 & \\
\hline 13 & NSB00133 & Edi Ruslah & 86 & 3720000 & 9500000 & 30 & \\
\hline 1 & & III & & - & & , & \\
\hline
\end{tabular}

Gambar 9. Form Training

5. Form Testing Hasil Keputusan

Setelah dilakukan proses training, maka dilanjutkan ke proses testing untuk menentukan nasabah mana yang layak mendapatkan kredit usaha dari pihak Adira Finance, ditunjukkan pada Gambar 10.

\begin{tabular}{|c|c|c|c|c|c|}
\hline KODE NASABAH & NAMA & $Y_{\text {_in uij }}$ & Y uii & Hasil Keputusan & Hasil Sur c \\
\hline NSB00001 & Prawoto & 55.66648716 & 0.8 & $\mathrm{ACC}$ & $A c c$ \\
\hline NSBO0002 & M.Samsul Huda & 81.32594209 & 0.8 & $\mathrm{ACC}$ & $\mathrm{Acc}$ \\
\hline NSBO0003 & Umi Nadliroh & 14.87687791 & 0.5 & $\mathrm{ACC}$ & Acc \\
\hline NSB00004 & Yohanes Kurniawan & 25.01254649 & 0.7 & $\mathrm{ACC}$ & $\mathrm{Acc}$ \\
\hline NSB00005 & Suwanto & 30.02069369 & 0.9 & $\mathrm{ACC}$ & $\mathrm{Acc}$ \\
\hline NSBO0006 & Imam Muslikin & 27.23554857 & 0.8 & $\mathrm{ACC}$ & $\mathrm{Acc}$ \\
\hline NSB00007 & Suwito & 17.84684849 & 0.7 & $\mathrm{ACC}$ & $\mathrm{Acc}$ \\
\hline NSBO0008 & Endang Siswanti & 20.75304096 & 0.9 & $\mathrm{ACC}$ & $\mathrm{Acc}$ \\
\hline NSBO0009 & Ella Dwi Mayangsari & 39.12529572 & 0.5 & $\mathrm{ACC}$ & $\mathrm{Acc}$ \\
\hline NSBO0010 & imam Syafii & 50.99624609 & 0.5 & $\mathrm{ACC}$ & Acc \\
\hline NSB00011 & Sumaji & 14.03007276 & 0.9 & $\mathrm{ACC}$ & $\mathrm{Acc}$ \\
\hline NSBO0012 & Eko Purharyadi & 15.09044369 & 0.6 & $\mathrm{ACC}$ & $\mathrm{Acc}$ \\
\hline NSB00013 & Arika Chandra & 20.89784854 & 0.5 & $A C C$ & $\mathrm{Acc}$ \\
\hline NSBO0014 & Sudewo & 88.77005708 & 0.9 & $\mathrm{ACC}$ & $\mathrm{Acc}$ \\
\hline 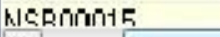 & Alikdustats & $1 A+073 A 518$ & $n 7$ & ACT & $\mathrm{Am}$ \\
\hline $1 \quad \square$ & & III & & & 1 \\
\hline
\end{tabular}

Gambar 10. Form Testing Hasil Keputusan 


\section{KESIMPULAN}

Berdasarkan percobaan yang telah dilakukan terhadap sistem maka dapat disimpulkan beberapa hal sebagi berikut:

1. Metode neural network terdapat dua proses, yaitu proses pelatihan (training) dan proses pengujian (testing). Pada proses pelatihan bertujuan untuk mencari bobot-bobot terbaik pada setiap layer.

2. Kriteria yang digunakan sebagai lapisan input arsitektur jaringan yaitu: lama usaha, pendapatan, jaminan, jangka waktu dan prestasi.

3. Aplikasi telah didesain mampu memenuhi kebutuhan pihak Pimpinan Adira dalam melakukan pemilihan nasabah mana yang layak dan tidak menerima kredit dengan nilai parameter learning rate sebesar 0.9; hidden layer 10 ; maksimum epoch 1000 dan target error $10^{-5}$ menghasilkan akurasi yang cukup baik yaitu $98 \%$.

\section{SARAN}

Untuk pengembangan lebih lanjut serta penyempurnaan sistem pendukung keputusan penentuan kelayakan penerima kredit usaha di Adira Finance menggunakan metode neural network, yaitu disarankan untuk menggunakan metode lain sehingga dapat dibandingkan hasil perhitungannya dan hasil nilai akurasinya.

\section{DAFTAR PUSTAKA}

[1] Prayetno., Muslihudin., 2013, Model Sistem Pendukung Keputusan Penilaian Kelayakan Pemberian Kredit, Jurnal Informatika, No. 1, Vol. 1, Hal 248-258

[2] Zein, H., 2014, Aplikasi Sistem Pendukung Keputusan Pemberian Kredit Usaha Rakyat Menggunakan Metode Simple Additive Weighting (SAW) (Studi Kasus Pada Bank Syariah Mandiri Cabang Medan), Jurnal Pelita Informatika Budi Darma, No. 1, Vol. 1, Hal. 164-167

[3] Sasmito, G. W., Somantri., 2015, Tsukamoto Method in Decision Support System for Realization of Credit on Cooperative, International Conference on Information Technology and Engineering Application, Palembang, 20-21 Februari 2015

[4] Andrijasa, Mistianingsih, 2010, Penerapan Jaringan Syaraf Tiruan untuk Memprediksi Jumlah Pengangguran di Provinsi Kalimantan Timur Menggunakan Algoritma Pembelajaran Backpropagation, Jurnal Informatika Mulawarman, No. 1, Vol. 5, Hal. 50-54

[5] Yulianti, L., 2013, Implementasi Jaringan Syaraf Tiruan Dalam Sistem Pendukung Keputusan untuk Memilih Perguruan Tinggi, Jurnal Media Infotama, No. 2, Vol. 9, Hal. 4563

[6] Yunitarini, R., 2014, Implementasi Metode Backpropagation pada Sistem Pendukung Keputusan Penentuan Harga Jual Perumahan, Jurnal Ilmiah Nero, No. 1, Vol. 1, Hal. 5-13 